\title{
PLANTS AS NATURAL REMEDIATION TOOLS
}

\author{
(C) Giorgi Kvesitadze, Tinatin Sadunishvili
}

\author{
Georgian National Academy of Sciences, Agricultural University of Georgia \\ Tbilisi, Georgia \\ science-almanac@mail.ru
}

As a result of production of chemicals, unpredictable growth of industry and transport, urbanization, the permanent increase of contamination of all biological sources by chemical compounds of toxic nature is observed. Naturally formed emission of poisonous gases, the washing of toxic elements out of ore during floods or earthquakes, formation by microorganisms toxic compounds in swamps, etc. are a very little input as compared with human anthropogenic contribution in environments contamination. Above 600 millions of tons of chemicals of are annually produced in the world. By different ways large amounts of these hazardous compounds or their incomplete metabolic transformations, still having high toxicity, are accumulated in biosphere significantly affecting the ecological balance. The great majorities of chemically synthesized stable compounds hardly undergo extra- or intracellular enzymatic transformations (plant protection and pest control agents, solvents and emulsifiers, etc.) and are especially dangerous for all kinds of organisms. Disposal of municipal sewage and wastes accumulated by industry should be also considered a priority for human settlements, as serious contamination source. Uncontrolled discharge of all kinds of wastes always creates functioning biological source of contamination. The elimination of contaminants from the environment by microorganisms of different taxonomic groups is a well established, genetically determined property, which has already been widely discussed. Plants ecological potential is under deep investigation in spite that its participation in creation of ecological balance has already been proved.

Key words: plants, remediation, production of chemicals, toxic compounds, taxonomic groups, ecological balance.

\section{[Г. Квеситадзе, Т. Садунишвили Растения как природное средство рекультивации]}

В результате производства химических веществ наблюдается непредсказуемый рост промышленности и транспорта, урбанизация, постоянное увеличение загрязнения всех биологических источников химическими соединениями токсичного характера. Естественно образовавшийся выброс ядовитых газов, промывка токсичных элементов из руды во время наводнений или землетрясений, образование токсичными соединениями микроорганизмов в болотах и т. д. являются очень небольшим вкладом по сравнению с антропогенным вкладом человека в загрязнение окружающей среды. В мире ежегодно производится свыше 600 миллионов тонн химикатов. Различными способами большие количества этих опасных соединений или их неполные метаболические превращения, все еще имеющие высокую токсичность, накапливаются в биосфере, что существенно влияет на экологический баланс. Большая часть химически синтезированных стабильных соединений вряд ли подвергается внешне- или внутриклеточным ферментативным превращениям (средства защиты растений и средства борьбы с вредителями, растворители и эмульгаторы и т.д.) особенно опасны для всех видов организмов. Утилизация муниципальных сточных вод и отходов, накопленных промышленностью, также должна считаться приоритетом для населенных пунктов, как серьезного источника загрязнения. Неконтролируемый сброс всех видов отходов всегда создает биологический источник загрязнения. Удаление загрязняющих веществ из окружающей среды микроорганизмами различных таксономических групп является хорошо установленным генетически определенным свойством, которое уже широко обсуждалось. Экологический потенциал растений широко исследуется, несмотря на то, что его участие в создании экологического баланса уже доказано.

Ключевые слова: растения, рекультивация, химикаты, токсичные соединения, таксономические группы, экологический баланс. 
Giorgi Kvesitadze - Ph.D. of biology, professor, president of Georgia national academy of sciences. Tbilisi, Georgia.

Tinatin Sadunishvili - Ph.D., academician of the Georgian national academy of sciences. Tbilisi, Georgia

Квеситадзе Гиорги - доктор биологических наук, профрессор, президент Национальной академии наук Грузии. Тбилиси, Грузия.

Тинатин Садунашвили - доктор наук, академик Национальной академии наук Грузии. Тбилиси, Грузия.

\section{Plants-detoxifiers of organic contaminants}

Until recently, plants, which still occupy about $40 \%$ of the world's land area, were considered as organisms just accumulating contaminants but having no potential to transform them into harmful compounds. According to the existing information, plants could only slightly transform toxic compounds, presumably oxidize, than conjugate and deposit in vacuoles.

Analysis of experimental data in the last two-three decades has revealed the visible ecological potential of plants. It has been exposed the deep degradation processes proceeding in higher plants, depending on the structure of contaminants quite often leading to mineralization or deep degradation (detoxification) of contaminants. As a result, enzymes carrying out partial/deep oxidation, conjugation and compartmentation processes have been revealed and characterised; the formation of anthropogenic contaminants conjugates with endogenous compounds is also well established natural process [10]. Although, there are still some unlearned steps in organic contaminants multistage detoxification carried out in plants, in this publication is making attempts for the evaluation of different aspects of plants ecological potential from the modern understanding, revealing the criterion for the evaluation of deviations under the action of contaminants in ultra structural architectonics of plant cells. Table 1 presents plants potential to absorb and metabolize some wide spread contaminants.

Table 1

\section{List of tested toxicants}

\begin{tabular}{|c|c|c|c|c|}
\hline $\begin{array}{l}\text { Hydrocarbo } \\
\text { ns }\end{array}$ & $\begin{array}{l}\text { Methane, } \\
\text { Ethane, } \\
\text { Propane, } \\
\text { Butane }\end{array}$ & $\begin{array}{l}\text { Pentane, } \\
\text { Hexane, } \\
\text { Cyclohexane }\end{array}$ & $\begin{array}{l}\text { Benzene, } \\
\text { Toluene, } \\
\text { Napthalene }\end{array}$ & $\begin{array}{l}\text { 1,2-Benz(a)anthracene, } \\
\text { 3,4-Benzpyrene, } \\
\text { Dibenz(a,h)antracene, } \\
\text { 3-Methylcholantrene }\end{array}$ \\
\hline $\begin{array}{l}\text { Organochlo- } \\
\text { rine solvents }\end{array}$ & Chloroform & & & \\
\hline Alcohols & $\begin{array}{l}\text { Methanol, } \\
\text { Ethanol }\end{array}$ & $\begin{array}{l}\text { Isopropanol, } \\
\text { Butanol }\end{array}$ & $\begin{array}{l}\text { Pentanol, } \\
\text { Hexanol }\end{array}$ & $\begin{array}{l}\text { Octanol, } \\
\text { Benzyl alcohol }\end{array}$ \\
\hline Phenols & $\begin{array}{l}\text { Phenol, } \\
\text { o-Cresol, } \\
m \text {-Cresol, } \\
p \text {-Cresol }\end{array}$ & $\begin{array}{l}\text { Catechol, } \\
\text { Hydroquinone, } \\
\text { Methylhydroqui- } \\
\text { none, } \\
\text { Resorcin }\end{array}$ & $\begin{array}{l}\text { Pyrogallol, } \\
\text { a-Naphthol, } \\
\text { Fluoroglu- } \\
\text { cine, } \\
\text { Thymol, } \\
\text { Guaiacol }\end{array}$ & $\begin{array}{l}\text { Oxyhydroquinone, } \\
\text { Toluhydroquinone, } \\
\text { Thymohydroquinone, } \\
\text { Durohydroquinone }\end{array}$ \\
\hline Quinones & $\begin{array}{l}\text { o- } \\
\text { Benzoqui- }\end{array}$ & $\begin{array}{l}\text { Toluquinone, } \\
\text { Timoquinone }\end{array}$ & $\begin{array}{l}\text { Duroquinone, } \\
\text { Anthraqui- }\end{array}$ & $\begin{array}{l}\text { 2-Methyl-1,4- } \\
\text { naphthoquinone, }\end{array}$ \\
\hline
\end{tabular}




\begin{tabular}{|c|c|c|c|c|}
\hline & $\begin{array}{l}\text { none, } \\
p \text { - } \\
\text { Benzoqui- } \\
\text { none } \\
\end{array}$ & & none & $\begin{array}{l}\text { 2-Hydroxy-1,4- } \\
\text { naphthoquinone }\end{array}$ \\
\hline $\begin{array}{l}\text { Aldehydes } \\
\text { and Ketones }\end{array}$ & $\begin{array}{l}\text { Formalde- } \\
\text { hyde }\end{array}$ & Acetaldehyde & Acetone & \\
\hline $\begin{array}{l}\text { Organic ac- } \\
\text { ids }\end{array}$ & $\begin{array}{l}\text { Formic acid, } \\
\text { Acetic acid }\end{array}$ & $\begin{array}{l}\text { Acetahydride, } \\
\text { Propionic acid }\end{array}$ & $\begin{array}{l}\text { Butyric acid, } \\
\text { Valeric acid }\end{array}$ & $\begin{array}{l}\text { Caproic acid, Benzoic ac- } \\
\text { id }\end{array}$ \\
\hline $\begin{array}{l}\text { Nitroderi- } \\
\text { vates }\end{array}$ & $\begin{array}{l}- \\
\text { Nitrophenol } \\
p- \\
\text { Nitrophenol }\end{array}$ & $\begin{array}{l}\text { 2,4-Dinitrophenol } \\
p \text {-Nitroanisole }\end{array}$ & $\begin{array}{l}\text { Nitrobenzene } \\
\text { Dinitroben- } \\
\text { zenes }\end{array}$ & $\begin{array}{l}\text { 2,4,6-Trinitrotoluene } \\
\text { (TNT) } \\
\text { Hexahydro-1,3,5-trinitro- } \\
\text { 1,3,5-triazin (RDX) }\end{array}$ \\
\hline Amines & Aniline & $\begin{array}{l}\mathrm{N}, \mathrm{N}- \\
\text { Dimethylaniline }\end{array}$ & Benzidine & \\
\hline $\begin{array}{l}\text { Pesticides } \\
\text { (Herbicides) }\end{array}$ & $\begin{array}{l}\text { Phenoxiace- } \\
\text { tic acid } \\
2,4- \\
\text { Dichloroa- } \\
\text { cetic acid } \\
(2,4-D)\end{array}$ & $\begin{array}{l}\text { Atrazine, Sima- } \\
\text { zine, } \\
\text { Lindane }\end{array}$ & $\begin{array}{l}\text { Carbaryl } \\
\text { (Sevan) }\end{array}$ & $\begin{array}{l}\text { 2,4-Dinitro-o-Cresol } \\
\text { (DNOC) Dichlorodiphenyl- } \\
\text { trichloroethane (DDT) }\end{array}$ \\
\hline Drugs & $\begin{array}{l}\text { Aminopy- } \\
\text { rine }\end{array}$ & Ethylmorphine & & \\
\hline
\end{tabular}

In spite of difficulties in quantitative, as well as qualitative estimation, and having a tendency to be increased, the level of spread-out contaminants in many places of the planet significantly exceeds maximally permissible standards. Most dangerous among these contaminants are considered as emergent because of their persistence, bioaccumulation, and toxicity along with our awareness of their prominent occurrence in the environment. In different ways, huge amounts of these hazardous substances or toxic intermediates of their incomplete transformations are accumulated in different niches of biosphere, significantly affecting ecological balance. Lately, the number of ecological technologies targeted to minimize the flow of toxic compounds into the biosphere and monitoring of their level have been developed. Despite some positive effect from the realization of these technologies (physical, chemical, mechanical etc), the intensive flow of toxic compounds to the biosphere is still increasing.

The international significance of this problem being determined by global migration of contaminants (migration between soil, air and water, geographical, biotic, etc.) leads to the distribution of toxic compounds of different structure and overall increase of the toxicity level. Nevertheless, the members of the plant kingdom assimilate toxic compounds, removing them from the environment, naturally providing long-term protection and monitoring against their environmental dispersal. Obviously, microorganisms and plants represent the main power of nature permanently defending the ecological balance. Plants being the most recently recognized as an important ecological tool and in order to properly evaluate their detoxification potential should be emphasized according to following features [3]:

- Higher plants simultaneously contact three main ecological niches: soil, water and air

- A well-developed root system of higher plants determines the soil-plant-microbial interaction, representing an unique process by producing exudates, significantly affecting the overall plant metabolism 
- The large assimilating surface area of plant leaves (adaxial and abaxial) significantly exceeds in size the corresponding aboveground surface located under the plant, and permits in addition to roots the absorption of contaminants in large quantities from the air via the cuticle and stomata

- The unique internal transportation system of plants in both directions, distributes all the penetrated compounds throughout the entire plant

- The autonomous synthesis of vitally important organics and extra energy by using intracellular potential highly supports the prolonged remediation process

- The existence of enzymes catalysing oxidation, reduction, hydrolysis, conjugation, compartmentation and other reactions of the multistage detoxification process

- The large intracellular space to deposit heavy metals and temporary conjugates of organic contaminants with regular cell compounds

- Functionalization and further transformation of organic contaminants by deep oxidation, carried out in plant cells

In order to penetrate into a leaf, xenobiotics (contaminants) should pass through the stomata, or traverse the epidermis which is covered by film-like wax cuticle. Generally, stomata are located on the lower (abaxial) side of a leaf, and the cuticular layer is thicker on the upper (adaxial) side. Gases and liquids penetrate through the stoma into the leaves. The permeability for gases depends on the degree of opening of stomata apertures $(4-10 \mathrm{~nm})$ and for liquids, on moistening of the leaf surface, the surface tension of the liquid and morphology of the stomata. The majority of toxic compounds of law and average molecular weight quite easily penetrate into a leaf as solutions (pesticides, liquid aerosols, etc.).

The contaminant penetration into the roots essentially differs from the leaves. Substances pass into roots only through unsuberized cell walls. Therefore, roots absorb substances much less selectively than leaves. Roots absorb environmental contaminants in two phases: in the first fast phase, substances diffuse from the surrounding medium into the root; in the second they gradually distribute and accumulate in the tissues. The intensity of the contaminants absorption process, characterized by various regulations, depends on the contaminant solubility, molecular mass, concentration, polarity, $\mathrm{pH}$, temperature, soil humidity, etc. [4]

Nowadays, there are experimentally demonstrated that plants activate a definite set of biochemical and physiological processes to resist the toxic action of contaminants by using following physiological/biochemical mechanisms:

- excretion;

- conjugation of contaminants with intracellular compounds following by compartmentalization of the conjugates in cellular structures;

- decomposition of environmental contaminants (or the significant part of their carbon skeleton) to standard cell metabolites or their mineralization.

Commonly, plants gradually degrade penetrated through cell wall organic contaminants to avoid their toxic action. According to contaminants assimilating potential plants sometimes are differing up to four orders of magnitude that allowed classifying plants as strong, average and weak absorbers of different structure contaminants. For instance, the most active assimilators uptake up to $10 \mathrm{mg}$ of benzene per $1 \mathrm{~kg}$ of fresh biomass per day, whereas the assimilation potential of the weak absorbers is measured in hundredths of $\mathrm{mg}$ (Table 2). 
Plants leafs potential to assimilate benzene and toluene

Table 2

\begin{tabular}{|c|c|c|c|}
\hline \multirow{2}{*}{ 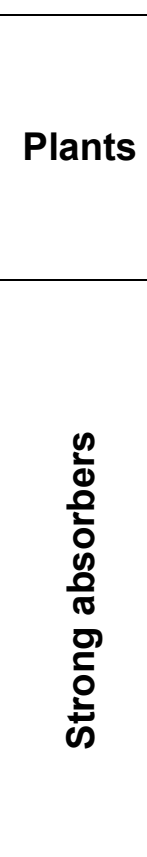 } & \multirow{2}{*}{ 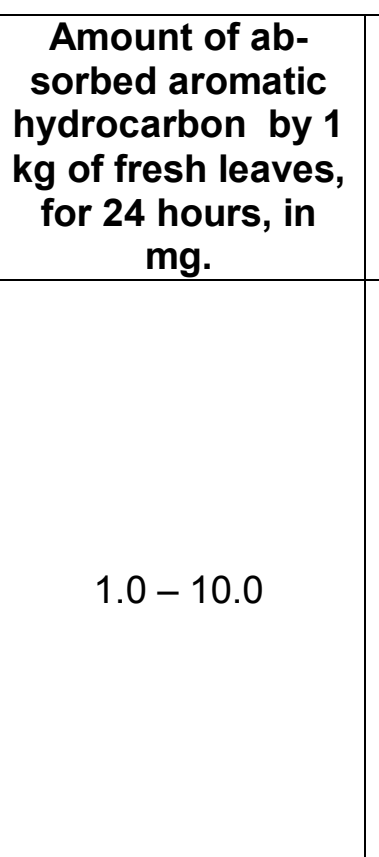 } & \multicolumn{2}{|c|}{ Plants } \\
\hline & & $\begin{array}{l}\text { Maple (Acer campestre) } \\
\text { Oleaster (Elaeagnus angusti- } \\
\text { folia) } \\
\text { Locust (Robina pseudoacacia) } \\
\text { Wild pear (Pyrus caucasica) } \\
\text { Walnut (Juglans regia) } \\
\text { Almond-tree (Amigdalus } \\
\text { communis) Cherry-tree } \\
\text { (Cerasus avium) } \\
\text { Amorpha (Amorpha fructico- } \\
\text { sa) } \\
\text { Cherry-tree (Cerasus vulgaris) } \\
\text { Chestnut (Castanea sativa) }\end{array}$ & \begin{tabular}{|l} 
Apple-tree (Malus domestica) \\
Zelkova (Zelcova caprinifolia) \\
Poplar (Populus canadensis) \\
Ryegrass (Lolium perene) \\
Lilac (Siringa vulgaris) \\
Weeping willow (Salix) \\
Catalpa (Catalpa bignoni- \\
oides) \\
Platan-tree (Platanus oriental- \\
is) \\
Sophora (Sophora japonica)
\end{tabular} \\
\hline 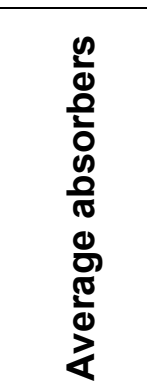 & $0.1-1.0$ & $\begin{array}{l}\text { Alder (Alnus barbata) } \\
\text { Asp (Populus tremula) } \\
\text { Elm (Ulmus filiacea) } \\
\text { Ash (Fraximus excelsior) } \\
\text { Tea (Camellia sinensis L.) } \\
\text { Persimmon (Diospyros lotus) } \\
\text { Bay laurel (Laurus nobilis) }\end{array}$ & $\begin{array}{l}\text { Gleditdchia (Gleditschia tria- } \\
\text { canthos) } \\
\text { Kidney (Phaseolus vulgaris) } \\
\text { Pine (Pinus) } \\
\text { Pine (Pinus eldarica) } \\
\text { Thuja (Tuja) } \\
\text { Apricot (Prunus armenicana) } \\
\text { Vine (Vitis vinifera) }\end{array}$ \\
\hline 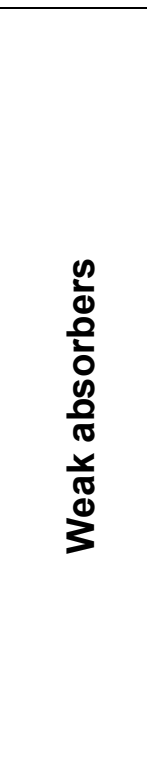 & $0.001-0.1$ & $\begin{array}{l}\text { Fir (Picea abies) } \\
\text { Mulberry (Morus alba) } \\
\text { Lime-tree (Tilia cauxasica) } \\
\text { Reed (Phragmites communis) } \\
\text { Maize (Zea mays) } \\
\text { Wild plum (Prunus divaricata) } \\
\text { Kiwi (Apteryx australis) } \\
\text { Aloe (Aloe) } \\
\text { Medlar (Mespilus germanica) } \\
\text { Rose (Rosa) } \\
\text { Platan-tree (Platanus) }\end{array}$ & $\begin{array}{l}\text { Cypress (Cupressus semper- } \\
\text { virens var.Pyramidalis) } \\
\text { Geranium (Pelargonium } \\
\text { roseum) } \\
\text { Privet (Ligustrum vulgare) } \\
\text { Fig (Ficus carica) } \\
\text { Pomegranate (Punica gran- } \\
\text { atum) } \\
\text { Rhododendron(Rhododendron } \\
\text { ponticum) } \\
\text { Peach-tree (Persica vulgaris) } \\
\text { Potato (Solanum tuberosum) } \\
\text { Tomato (Lycoperssicum escu- } \\
\text { lentum) } \\
\text { Pussy-willow (Salix alba) } \\
\text { Cherry-plum (Prunus } \\
\text { vachuschtii) }\end{array}$ \\
\hline
\end{tabular}




\section{Mechanisms of organic contaminants transformation in plant cells}

The fate of the entered plant cell contaminants depends on their chemical nature, external temperature, variety of plants and phase of vegetation, etc. The simplest pathway of entered the plant cell organic contaminants is excretion. The essence of excretion is that the toxic molecule does not undergo chemical transformation, and being translocated through the apoplast, it is excreted from the plant. This pathway of xenobiotics (contaminants) elimination is rather rare and takes place at high concentrations of highly mobile (phloem-mobile or ambi-mobile) xenobiotics.

In the majority of cases, contaminants being absorbed and penetrated into plant cell undergo enzymatic transformations leading to increase of its hydrophilicity - process simultaneously accompanied by contaminants toxicity decreasing. Below are presented successive phases of contaminant initial transformations in accordance with Sandermann's "green liver" concept [7] (Fig. 1):

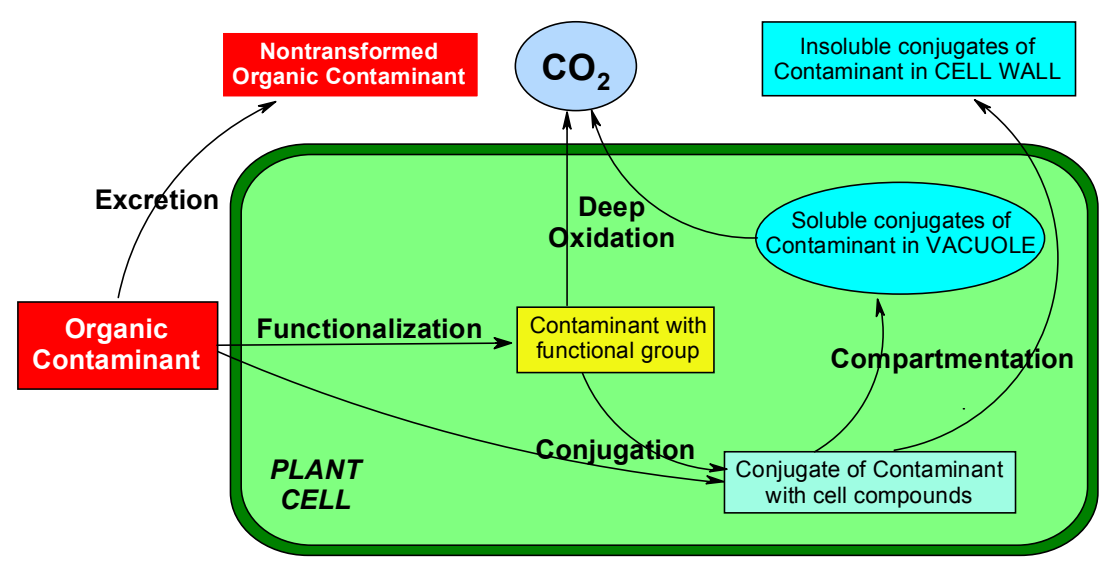

Fig. 1. The main pathways of organic contaminant transformation in plant cells

Functionalization is a process whereby a molecule of a hydrophobic organic xenobiotic acquires a hydrophilic functional group (hydroxyl, carboxyl, amino, etc.) as a result of enzymatic oxidation, reduction, hydrolysis, etc. Due to the introduction of functional group, the polarity and corresponding reactivity of the toxicant molecule is enhanced. This promotes an increase of intermediate's affinity to enzymes, catalyzing further transformation.

Conjugation takes place as a basic process of phytoremediation and is determined by the formation of chemical coupling of the contaminant to the endogenous cell compounds (proteins, peptides, amino acids, organic acids, mono-, oligo-, polysaccharides, lignin, etc.) and so forming peptide, ether, ester, thioether or other type covalent bonds between contaminants and endogenous cell compound. Intermediates of the contaminant initial transformations or those contaminants which themselves possessing functional groups capable of reacting with intracellular endogenous compounds, are all susceptible to conjugation.

Commonly, the main part of the toxicant molecules undergoes conjugation and only a small amount is deeply degraded $(0.1-2 \%$, depending on structure of contaminants). Conjugation is a widespread defence mechanism in higher plants, especially in cases when the penetrated contaminant concentration is exceeding the plant transformation (decomposition) potential. Increased amounts of deep degradation to regular plant sell metabolites, or $\mathrm{CO}_{2}$ and water, most often is achieved in the case of linear, low molecular weight structures of contaminants. The toxicity of the conjugates compared to parent com- 
pounds (initial contaminant) is significantly decreased due to creating the formation of a new compound containing large non-toxic part. Conjugates are kept in the cell for a certain period of time without causing visible pathological deviations in cell homeostasis. The conjugate formation also gives the plant cell extra time for the internal mobilization, and the induction of enzymes responsible for contaminants further transformation. Relatively quickly (depending on plant variety, contaminants structure and concentration), after the termination of plant incubation with the contaminant, conjugates are no longer found in plant cells.

Some attempts have been made by authors (unpublished data) to estimate different plant (soybean, ryegrass, alfalfa) cells' internal volume potential to accumulate conjugated benzene in their cells in the case of toxicants saturation. In spite of incomplete information, it was supposed that for genetically non-modified plants, it could be at least several molecules of contaminant conjugates per one plant sell. Although conjugation is the most widely distributed pathways of plant self-defence, it cannot be assumed as energetically and physiologically advantageous for metabolic processes in plants. Firstly, the formation of conjugates leads to the depletion of vitally important cellular compounds, and secondly, unlike deep degradation, the formation of conjugates maintains unchanged the contaminant basic molecular structure, and hence results only in partial and provisional decreasing of its toxicity.

Compartmentation in most cases is the final step of conjugates processing. Soluble conjugates of toxic compounds (coupled with peptides, sugars, amino acids, etc.) are accumulated in the cell structures (primarily in vacuoles), while insoluble conjugates (coupled with lignin, starch, pectin, cellulose, xylan) are moved out of the cell via exocytosis into the apoplast and accumulated in the cell wall. The compartmentalization process is similar to mammalian excretion, essentially removing/eliminating the toxic part from metabolic tissues. The major difference between detoxification in mammals and plants is that plants do not have a special excretion system for the removal of contaminant conjugates from the organism. Hence, they use a mechanism of active transport for the removal of the toxic residues away from the vitally important sites of the cell (nuclei, mitochondria, plastids, etc.). This active transport is facilitated and controlled by the ATP-dependent glutathione pump and is known as "storage excretion".

The above described pathway of toxic compound processing, i.e., functionalization $\rightarrow$ conjugation $\rightarrow$ compartmentation, is well illustrated by the processing of anthropogenic contaminants of different structures. One of such examples demonstrating the transformation of organochlorine pesticides is the hydroxylation of 2,4-D followed by conjugation with glucose and malonyl residues and deposition in vacuoles [5].

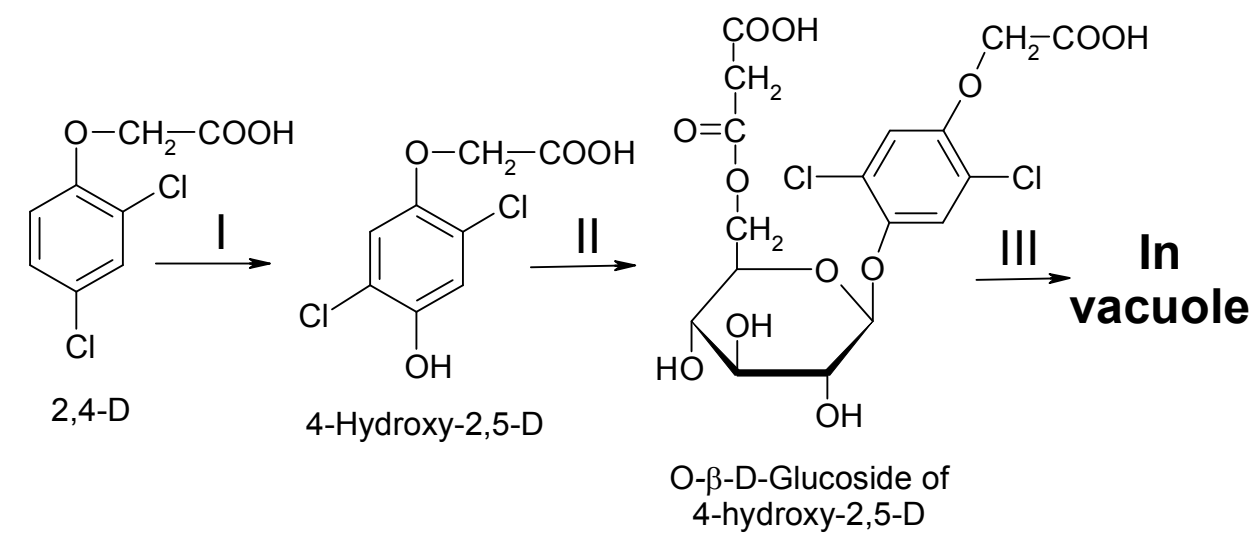

2,4-D transformation for deposition in vacuoles 
Anthropogenic organic toxicants decomposition processes are closely related to many aspects of plants cellular metabolism. In prolonged and multifunctional detoxification processes quite a few enzymes are actively involved. According to catalyzed reactions they are directly or indirectly participating in detoxification process.

\section{Enzymes}

The great majority of contaminants chemical transformation during functionalization, conjugation and compartmentation are of enzymatic nature. It is remarkable that due to their unusual flexibility in the absence of contaminants, in plant cell these enzymes catalyze reactions typical for regular plant cell metabolism. Based on multiple literature data the following enzymes directly participate in the transformation process of anthropogenic contaminants:

- Oxidases, catalyzing hydroxylation, dehydrogenation, demethylation and other oxidative reactions (cytochrome P450-containing monooxygenase, peroxidase, phenoloxidase, ascorbatoxidase, catalase, etc.)

- Reductases, catalyzing the reduction of nitro groups (nitroreductase)

- Dehalogenases, splitting atoms of halogens from halogenated and polyhalogenated xenobiotics

- Esterases, hydrolyzing ester bonds in pesticides and other organic contaminants.

The first step of contaminates transformation in majority of cases is carried out by oxidative enzymes, the most often contaminants oxidation is performed by the following metabolically active enzymes having the various metabolic functions:

Cytochrome P450-containing monooxygenases are mixed-function enzymes located in the membranes of the endoplasmic reticulum (microsomes). Monooxygenase system contains redox-chain for electron free transport, the initial stage of electron transfer is a NADPH-cytochrome P450 reductase (EC 1.6.2.4); the intermediate carrier-cytochrome $b_{5}$, and the terminal acceptor of electrons-cytochrome P450. When NADPH is used as the only source of reductive equivalents, the existence of an additional carrier, a NADHdependent flavoprotein is required. NADH may also be oxidized by the NADPH-dependent redox system. In the latter case cytochrome $b_{5}$ is not required. The cytochrome P450containing monooxygenases use NADPH and/or NADH reductive equivalents for the activation of molecular oxygen and incorporation of one of its atom into lipophilic organic compounds $(\mathrm{XH})$ that results in formation of hydroxylated products $(\mathrm{XOH})$. The second atom of oxygen is used for the formation of a water molecule (Fig. 2).

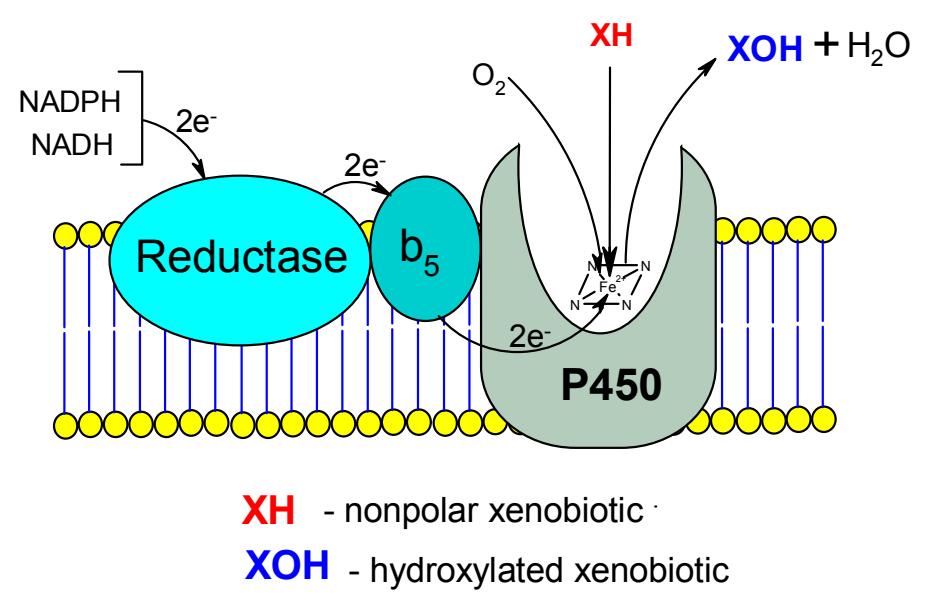

Fig. 2. Microsomal monooxygenase system 
Plant cytochrome P450-containing monooxygenases play an important role in the hydroxylation of organic contaminants. The enzymes participate in the reactions of $\mathrm{C}$ - and $\mathrm{N}$-hydroxylation of aliphatic and aromatic compounds, N-, O-, and S-dealkylation, sulphooxidation, deamination, $\mathrm{N}$-oxidation, oxidative and reductive dehalogenation, etc. [6] The resistance of plants against herbicides is mediated by their rapid intracellular transformation into hydroxylated products and subsequently conjugated to carbohydrate moieties in the plant cell wall. For examples, N-demethylation and ring-methyl hydroxylation of the phenylurea herbicide chlorotoluron in wheat and maize is cytochrome P450-dependent processes. For some phenyl urea herbicides in the Jerusalem artichoke cytochrome P450mediated $\mathrm{N}$-demethylation is sufficient to cause significant or complete loss of phytotoxicity [7-9].

Peroxidase. In higher plants, peroxidase activity increases in response to stress. The great catalytic versatility of the peroxidase is its predominant characteristic and, therefore, no single role exists for this multifunctional enzyme.

- The peroxidase is defined by the following reaction:

$-\mathrm{RH}_{2}+\mathrm{H}_{2} \mathrm{O}_{2} \rightarrow 2 \mathrm{H}_{2} \mathrm{O}+\mathrm{R}$

- The peroxidases catalyze a number of free radical reactions. Alternatively, the compound that is directly oxidized by the enzyme further oxidizes other organic compounds, including xenobiotics. This notion is based on the wide ubiquitous distribution of this enzyme in plants (the isozymes of peroxidase in green plants occur in the cell walls, plasmalemma, tonoplasts, intracellular membranes of endoplasmic reticulum, plastids and cytoplasm), and the high affinity and wide substrate specificity of plants peroxidases to organic xenobiotics of different chemical structures. The participation of plant peroxidases in hydroxylation reactions of xenobiotics has been widely discussed. For example, peroxidases from different plants are capable of oxidizing N,N-dimethylaniline, 3,4-benzpyrene, 4-nitro-o-phenylendiamine, 4-chloroaniline, phenol, aminoflourene, acetaminophen, diethylstilbestrol, butylated hydroxytoluene, hydroxyanisoles, benzidine; horseradish (Armoracia rusticana) peroxidase oxidizes tritium-labelled $\left[\mathrm{C}^{3} \mathrm{H}_{3}\right]$ TNT [3].

Phenoloxidases, group of the copper-containing enzymes (other namestyrosinase, monophenol monooxygenase, phenolase, monophenol oxidase, etc.) are spread within the plant cell organelles catalyzing both monooxygenase and oxygenase reactions: the o-hydroxylation of monophenols (monophenolase reaction) and the oxidation of $o$-diphenols to $o$-quinones (diphenolase reaction). Currently accepted enzyme nomenclature classifies hydroxylating phenol oxidase as monophenol monoxygenase (EC. 1.14.18.1) and o-diphenols oxidizing phenol oxidase as catechol oxidase (EC 1.10.3.1). Plant phenol oxidases appear to be a group of specific enzymes, oxidizing wide range of o-diphenols, such as DOPA (dihydroxyphenylalanine), catechol, etc, but unable to convert $m$ - or $p$ - diphenols to the corresponding quinons, Substrate specificity of catechol oxidase from Lucopus europaeus and characterization of the bioproducts of enzymatic caffeic acid oxidation. The active center of phenol oxidases contains two cooper atoms and exists in three states: "met', "deoxy" and "oxy". Phenoloxidases actively participate in the oxidation of xenobiotics of aromatic structure. As it has been demonstrated phenoloxidase from spinach, analogously to many other plants, oxidizes aromatic xenobiotics (benzene, toluene), by their hydroxylation and further oxidation to quinone. In a number of the cases, if the xenobiotic is not a substrate for the phenoloxidase, it may undergo co-oxidation in the following manner: the enzyme oxidizes the corresponding endogenous phenol by forming quinones or semi-quinones or both, i.e. compounds with a high redox potential. These compounds activate molecular oxygen by forming oxygen radicals, such as superoxide anion radical $\left(\mathrm{O}^{2-}\right)$ and hydroxyl radical $(\cdot \mathrm{OH})$, that gives compounds the capacity for the fur- 
ther oxidation of xenobiotic. The formation of these radicals enables phenoloxidase to participate in contaminants degradation processes also by co-oxidation mechanism presented below [8].

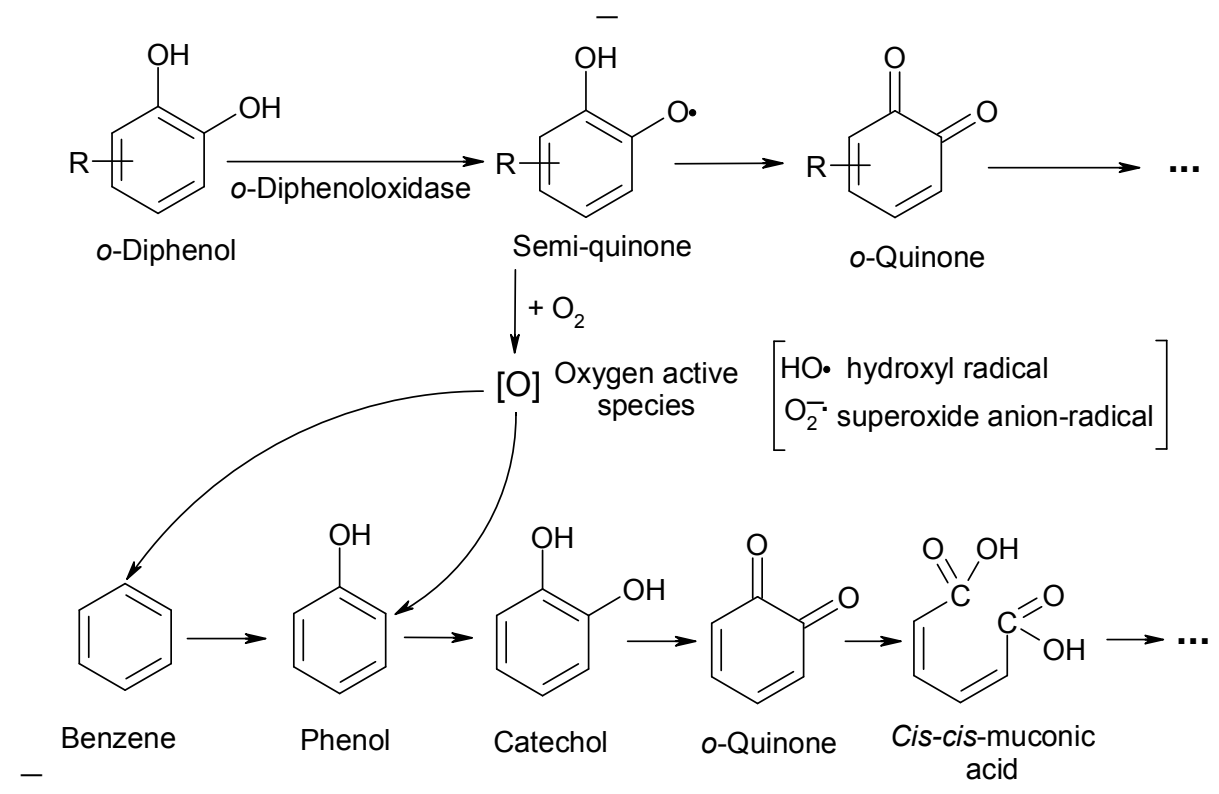

Fig. 3. Enzymatic oxidation of o-diphenols (upper) by phenoloxidase and non-enzymatic co-oxidation of benzene (lower)

Analogously, nitrobenzene is oxidized to $m$-nitrophenol, and the methyl group of $\left[\mathrm{C}^{3} \mathrm{H}_{3}\right]$ TNT is oxidized by phenoloxidase from tea plant. The information confirming participation of this enzyme in the oxidative degradation of xenobiotics in higher plants is sparse, despite the fact that participation of phenoloxidase should definitely be expected while xenobiotics degradation. Laccase of basidial fungi, analogous to higher plant phenoloxidase, have been better explored. Laccase degrades different aliphatic and aromatic hydrocarbons, and actively participates in the enzymatic oxidation of alkenes. Crude preparations of laccase isolated from the white rot fungus Trametes versicolor oxidizes 3,4benzopyrene, anthracene, chrysene, phenanthrene, acenaphthene and some other PAHs. The intensity of oxidation of these antropogenic contaminants is increased in the presence of such mediators as: phenol, aniline, 4-hydroxybenzoic acid, 4-hydroxybenzyl alcohol, methionine, cysteine, reduced glutathione, and others compounds-substrates of laccase. These data indicate that in the cases of fungal laccase and plant o-diphenoloxidase, the oxidation of hydrocarbons is carried out by a co-oxidation mechanism.

Conjugation reactions of contaminants in plant cell are catalyzed by transferases: glutathione S-transferase (GST), glucuronozyl-O-transferase, malonyl-O-transferase, glucosyl-O-transferase, etc [8]. Compartmentation of intermediates of contaminants transformation-conjugates takes place under the action of ATP-binding cassette (ABC) transporters. Depending on the structure of the contaminant some other enzymes may also be involved in their degradation process.

Prolonged in time cellular decomposition of contaminants involves participation of enzymes providing plant cell with extra energy needed for the defence processes, induction of the enzymes, and provision of cells by vitally important secondary metabolites. Enzymes involved in these and similar processes obviously indirectly participate in the contaminants detoxification processes. The correlation between the penetration of organic 
contaminants (alkenes, aromatic hydrocarbons, polycyclic aromatic hydrocarbons) in plant cells and the corresponding changes in the activities of enzymes participating in energy supply (malate dehydrogenase) and nitrogen metabolism (glutamate dehydrogenase, glutamine synthetase) has been revealed. As it has been shown the activities of the enzymes are highly affected by xenobiotics concentration, exposure time and mode of illumination [8].

Ecologically the most advantageous pathway of organic contaminants transformation in plants is their deep oxidative degradation to the level of regular cellular metabolites or mineralization. In plants mainly the following enzymes are responsible for this process: cytochrome P450-containing monooxygenese, peroxidase and phenoloxidase. To correctly evaluate the universality of the action of these enzymes, responsible for the degradation of different structure organic contaminants, some of their specificities should be emphasized (Table 3).

Table 3

\section{Plants oxidative metalloenzymes}

\begin{tabular}{|c|c|c|c|c|c|c|}
\hline Enzyme & $\begin{array}{l}\text { Physiologi- } \\
\text { cal function }\end{array}$ & $\begin{array}{l}\text { Existence } \\
\text { in cell }\end{array}$ & $\begin{array}{l}\text { Localiza- } \\
\text { tion }\end{array}$ & $\begin{array}{l}\text { Specifici- } \\
\text { ty to toxi- } \\
\text { cants }\end{array}$ & $\begin{array}{l}\text { Limiting } \\
\text { factors }\end{array}$ & Stability \\
\hline 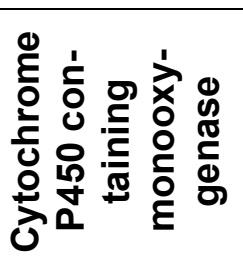 & $\begin{array}{l}\text { Participation } \\
\text { in a number } \\
\text { of intracellular } \\
\text { synthesizing } \\
\text { reactions }\end{array}$ & $\begin{array}{l}\text { Small } \\
\text { amount, } \\
\text { inductive } \\
\text { nature }\end{array}$ & $\begin{array}{l}\text { Endoplas- } \\
\text { matic reticu- } \\
\text { lum, cyto- } \\
\text { sole }\end{array}$ & $\begin{array}{l}\text { Very high } \\
\text { affinity to } \\
\text { nonpolar } \\
\text { toxicants }\end{array}$ & $\begin{array}{l}\text { NADPH, } \\
\text { NADH }\end{array}$ & $\begin{array}{l}\text { Labile, } \\
\text { inactivat- } \\
\text { ing dur- } \\
\text { ing sub- } \\
\text { strate } \\
\text { oxidation }\end{array}$ \\
\hline 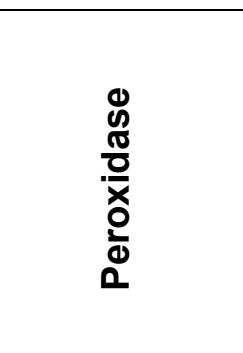 & $\begin{array}{l}\text { Hormonal } \\
\text { regulation, } \\
\text { lignification, } \\
\text { response on } \\
\text { stress, } \\
\text { removing of } \\
\text { peroxides }\end{array}$ & $\begin{array}{l}\text { Large } \\
\text { amount, } \\
\text { inductive } \\
\text { nature }\end{array}$ & $\begin{array}{l}\text { Cell } \\
\text { wall,vacoule } \\
\text { s, cytosole, } \\
\text { tonoplasts, } \\
\text { plastids, } \\
\text { plasma- } \\
\text { lemma }\end{array}$ & $\begin{array}{l}\text { Affinity to } \\
\text { aliphatic } \\
\text { com- } \\
\text { pounds }\end{array}$ & $\begin{array}{l}\text { Hydrogen } \\
\text { peroxide } \\
\text { or organic } \\
\text { hydroper- } \\
\text { oxides }\end{array}$ & Stable \\
\hline $\begin{array}{l}\text { D } \\
\frac{0}{0} \\
\frac{0}{x} \\
\frac{0}{0} \\
\frac{0}{0} \\
\frac{0}{0}\end{array}$ & $\begin{array}{l}\text { Oxidative } \\
\text { transfor- } \\
\text { mation of } \\
\text { phenols, ligni- } \\
\text { fication, cell } \\
\text { defence re- } \\
\text { actions }\end{array}$ & $\begin{array}{l}\text { Large } \\
\text { amount, } \\
\text { presents } \\
\text { in latent } \\
\text { form too, } \\
\text { inductive } \\
\text { nature }\end{array}$ & $\begin{array}{l}\text { Chloro- } \\
\text { plasts, cell } \\
\text { wall, cyto- } \\
\text { sole, tono- } \\
\text { plasts }\end{array}$ & $\begin{array}{l}\text { Affinity to } \\
\text { aromatic } \\
\text { com- } \\
\text { pounds }\end{array}$ & $\begin{array}{l}\text { Endoge- } \\
\text { nous phe- } \\
\text { nols }\end{array}$ & Stable \\
\hline
\end{tabular}

\section{Contaminants action on plant ultrastructure}

To evaluate the ecological potential of plants, the data proving the responses at the level of cellular ultrastructure under the action of contaminants, as the most precise indications of plants exploitation, should also be emphasized [11]. Undoubtedly, penetration of even a small concentration of contaminants into plant cells leads to invisible, but most often measurable deviations in cell metabolic processes such as induction of enzymes, inhibition of some intracellular metabolic processes, change the level of secondary metabolites, etc [4]. The existence of plant cell contaminants in increased concentrations provokes clearly noticeable deviations in cellular ultrastructure under the action of contami- 
nants, as the most precise indications of plants ultrastructural organization. It has been shown that the complex of changes and alterations in the main metabolic processes of plant cell elicited by organic pollutants (pesticides, hydrocarbons, phenols, aromatic amines, etc.) is connected with the deviations of cell ultrastructural architecture. The sequence and deepness of the destruction in plant cell organelles are highly variable and determined by the variety of plant, chemical nature, concentration and duration of the contaminant action, etc. This course of events has been experimentally demonstrated by authors in a number of various higher plants exposed to different ${ }^{14} \mathrm{C}$-labelled toxic compounds [5]. Due to the penetration of contaminants in plant cells changes in ultrastructural organization has been shown. Apparently, the negative effects of toxic compounds on cell ultra structure, depending on its concentration, could be divided in two types, being different for each contaminant and plant:

- change of metabolic activity which is digested by the plant even in case of insignificant negative effect;

- lethal, leading to indigestible deviations and to the plant death.

Figure 4 shows maize root apex cells exposed to ${ }^{14} \mathrm{C}$-nitrobenzene action, its penetration across the plasmalemma and localization in subcellular organelles. Studies of penetration of ${ }^{14} \mathrm{C}$-labelled xenobiotics into the plant cell indicate that the labelled compounds at the early stages of exposure (5-10 $\mathrm{min}$ ) are detected in the cell membrane, in the nuclei and nucleolus (in small amounts) and, seldom, in the cytoplasm and mitochondria. As a result of prolonged exposure the amount of a label significantly increases in the nucleus, at the membranes of organelles, in tonoplasts, and further in vacuoles, i.e. xenobiotic becomes distributed in most of subcellular organelles, but ultimately, there is a tendency of contaminants primary accumulation in vacuoles.
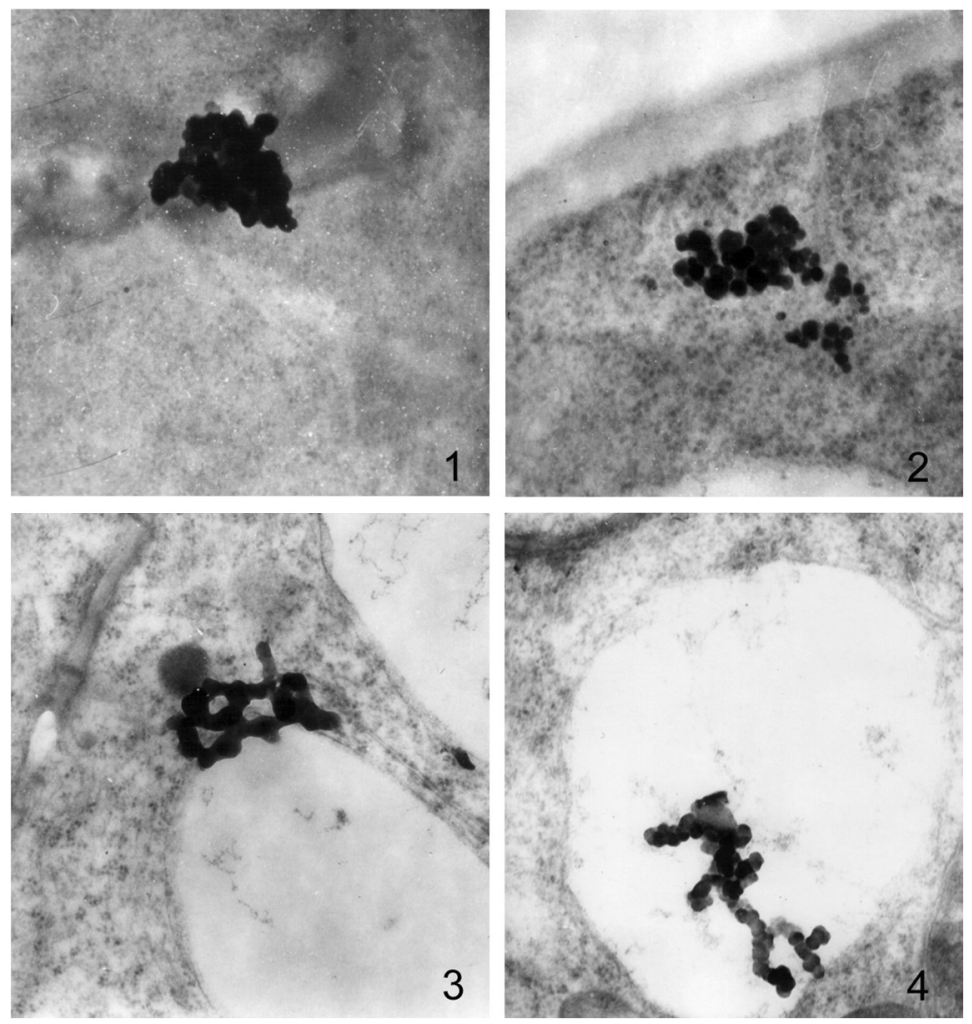

Fig. 4. Electron micrographs showing the penetration and movement of ${ }^{14} \mathrm{C}$-labelled nitrobenzene $(0.15 \mathrm{mM})$ in a maize root apex cell 
The xenobiotic penetrated through the plasmalemma, moved to the cytoplasm, and thereafter translocated into vacuoles.

\section{1 - × 48 000; 2 - × 36 000; 3 - × 50 000; 4 - × 30000}

\section{General considerations}

Obviously plants, as remediators, for a long time act most effectively at low and shallow contaminations of soil and air, when no significant changes in cell ultrastructure take place. Planting of almost any kind of vegetation, including agricultural annual and perennial plants is beneficial for the environment. However, in order to make the exploitation of the most ecological potential of each particular plant, the selection should be carried out according to the plants potential to assimilate/accumulate toxic compounds of different structure.

Phytoremediation is a unique cleanup strategy. The realization of phytoremediation technologies implies the planting on a contaminated area with one or more specific, previously selected plant species with the potential to extract contaminants from soil. A precise survey of the vegetation on site should be undertaken to determine what species of plants would have the best growth on the contaminated site. Based on a number of experimental results including the use of labeled xenobiotics and electron microscopic observations of authors in correlation with corresponding enzyme activities, the deep degradation of anthropogenic contaminants in plants could be considered as narrow but permanently acting pathway having much less potential than conjugates formation process (especially in case of contaminants saturation).

Obviously, the attempts to improve artificially ecological potential of higher plants will be continued and the results will be more substantial from the viewpoint of their eventual practical realization. The positive effect of these investigations could be much more impressive if all aspects of the quite complicated and multistage detoxification process would be better elucidated with regard to plant physiology and biochemistry. Such information would allow the creation of more rational and effective strategy for the gene engineering potential application [9].

The cost of phytoremediation technologies. Bioremediation is a completely natural process based on the joint detoxification action of plants and microorganisms. Phytoremediation technologies are economically competitive, compared with existing conventional ones. Dozens of scaled up examples have demonstrated the superiority of plantbased remediation technologies, mainly due to the following reasons: phytoremediation, being a natural, solar energy-driven process, does not require any additional energetic or significant material or other input; phytoremediation takes place in situ and requires no digging or hauling; little mechanical equipment is needed to operate the phytoremediation process. The cost components for the implementation of phytoremediation technologies include:

- detailed characterization of the polluted site (type of soil, rainfall, type of contaminant(s), concentration of contaminant(s), etc.);

- selection of appropriate plants and consortia of microorganisms (bacteria, fungi);

- the corresponding irrigation system;

- capital cost, materials, monitoring, including required instrumentation, indirect costs, etc.;

- operation and maintenance (labour, materials, chemicals, laboratory analyses, etc.).

Phytoremediation offers cost advantages, but it should be underlined that the time needed for full remediation is typically lengthy. Table 4 gives estimates of the costs of phytoremediation as compared with existing conventional technologies. 


\section{Estimated cost savings through the use of phytoremediation rather than conventional treatment, according to EPA data}

\begin{tabular}{|c|c|c|c|c|c|}
\hline \multirow{2}{*}{$\begin{array}{l}\text { Contaminant } \\
\text { and matrix }\end{array}$} & \multicolumn{2}{|c|}{ Phytoremediation } & \multicolumn{2}{|c|}{ Conventional Treatment } & \multirow{2}{*}{$\begin{array}{l}\text { Projected } \\
\text { savings }\end{array}$} \\
\hline & Application & Estimated cost & Application & $\begin{array}{c}\text { Estimated } \\
\text { cost }\end{array}$ & \\
\hline $\begin{array}{l}\text { Lead in soil } \\
\qquad(1 \text { acre })\end{array}$ & $\begin{array}{l}\text { Extraction, } \\
\text { harvest, and } \\
\text { disposal }\end{array}$ & $\begin{array}{l}\$ 150,000- \\
250,000\end{array}$ & $\begin{array}{l}\text { Excavate and } \\
\text { landfill }\end{array}$ & $\$ 500,000$ & $50-65 \%$ \\
\hline $\begin{array}{l}\text { Solvents in } \\
\text { groundwater } \\
\text { ( } 2.5 \text { acres) }\end{array}$ & $\begin{array}{l}\text { Degradation } \\
\text { and hydrau- } \\
\text { lic control }\end{array}$ & $\begin{array}{l}\$ 200,000 \text { for } \\
\text { installation and } \\
\text { initial mainte- } \\
\text { nance }\end{array}$ & $\begin{array}{l}\text { Pump and } \\
\text { treat }\end{array}$ & $\begin{array}{l}\$ 700,000 \\
\text { annual oper- } \\
\text { ating cost }\end{array}$ & $\begin{array}{l}50 \% \text { cost } \\
\text { saving by } \\
\text { the } 3^{\text {rd }} \text { year }\end{array}$ \\
\hline $\begin{array}{l}\text { Total petroleum } \\
\text { hydrocarbons in } \\
\text { soil ( } 1 \text { acre) }\end{array}$ & $\begin{array}{l}\text { In situ deg- } \\
\text { radation }\end{array}$ & $\begin{array}{l}\$ 50,000- \\
100,000\end{array}$ & $\begin{array}{l}\text { Excavate and } \\
\text { landfill or in- } \\
\text { cinerate }\end{array}$ & $\$ 500,000$ & $80 \%$ \\
\hline
\end{tabular}

Plants solely or in combination with specially selected microorganisms (or their consortia), are very promising detoxifiers allowing to create ecologically friendly technologies around or along hotbeds of contamination. Ecotechnologies based on the use of microorganisms and plants represent natural and the most effective way of remediation potential realization to clean up any kind of pollution in soil. Elaboration of a new ecological concept, unifying experience accumulated for last 3-4 decades and based on effective use plants and microorganisms joint (symbiotic) potential should be highly beneficial, by increasing its ecological potential.

\section{References}

1. Arziani B., Ugrekhelidze D., Kvesitadze G. Detoxication mechanism of exogenous monoatomic phenols in pea seedlings // Ecotoxicology and Environmental Safety. 2002. No 51.

2. Gordeziani M., Khatisashvili G., Ananiashvili T., Varazashvili T., Kurashvili M., Kvesitadze G. Tkhelidze P. Energetic significance of plant monooxygenase individual components participating in xenobiotic degradation // International Biodeterioration and Biodegradation. 1999. No 44.

3. Korte F., Kvesitadze G., Ugrekhelidze D., Gordeziani M., Khatisashvili G., Buadze O., Zaalishvili G., Coulston F. Review: Organic toxicants and plants // Ecotoxicology and Environmental Safety. 2000. No 47.

4. Kvesitadze G., Khatisashvili G., Sadunishvili T., Evstigneeva Z.G. Metabolism of anthropogenic toxicants in higher plants. M., 2005.

5. Kvesitadze G., Khatisashvili G., Sadunishvili T., Kvesitadze E. Plants for Remediation: Uptake, Translocation and Transformation of Organic Pollutants // Plants, Pollutants and remediation. Springer, 2015.

6. Morant M., Bak S., Moller B.L, Werck-Reichhart D. Plant Cytochromes P450: tools for pharmacology, plant protection and phytoremediation // Curr Opin Biotechnol 2. 2003.

7. Sandermann H. Higher plant metabolism of xenobiotics: the "green liver" concept // Pharmacogenetics. No 4. 1994

8. Schuler M.A. Plant Cytochrome P450 monooxygenases // Critical Review Plant Science. No 15. 1996. 
9. Tsao D. T. Phytoremediation. Advances in biochemical engineering and biotechnology. Berlin, New York, 2003.

10. Zaalishvili G., Khatisashvili G., Ugrekhelidze D., Gordeziani M., Kvesitadze G. Plant potential for detoxification // Applied Biochemistry and Microbiology. 2000. No 36.

11. Zaalishvili G., Sadunishvili T. Scalla R, Laurent F., Kvesitadze G. Electron Microscopic Investigation of Nitrobenzene Distribution and Effect on Plant Root Tip Cells Ultrastructure // Ecotoxicology and Environmental Safety. 2002. No 52. 